\title{
The Origins of Pauline Theology: Paratexts and Priscillian of Avila's Canons on the Letters of the Apostle Paul
}

\author{
T. J. LANG \\ University of St Andrews, St Mary's College, South Street, St Andrews, KY16 9JU, \\ United Kingdom.Email: tjl5@st-andrews.ac.uk \\ MATTHEW R. CRAWFORD \\ Institute for Religion and Critical Inquiry, Australian Catholic University, Locked \\ Bag 4115 DC, Fitzroy, VIC 3065, Australia. Email: matthew.crawford@acu.edu.au
}

\begin{abstract}
Pauline theology is a well-established undertaking in modern New Testament studies, and yet it is almost entirely without precedent prior to the nineteenth century. This article explores the enterprise of Pauline theology by considering an important and overlooked exception to its otherwise exclusively modern provenance: Priscillian of Avila's fourth-century Canons on the Letters of the Apostle Paul. The key to Priscillian's dogmatic synthesis of Paul's thought was his innovative 'versification' of Paul's letters, which facilitated efficient citation and cross-referencing of epistolary data. This article uses Priscillian's literary creation to examine the intriguing correlation of technologies for ordering textual knowledge with the systematic abstraction of Pauline theology.
\end{abstract}

Keywords: Pauline theology, Priscillian of Avila, paratexts, versification, codex, Eusebius of Caesarea

\section{Introduction}

The form in which we encounter a text always affects how we interpret its contents. ${ }^{1}$ Whether vellum or voice, volumen or codex, scriptio continua or chapter and verse, no medium or technology is inert in its influences on those who use it. John Locke learned this as he began work on his Paraphrase and

1 This fact has been emphasised most influentially in recent years by D. F. McKenzie, and especially in his now famous essay, 'Typography and Meaning: The Case of William Congreve', available in Making Meaning: 'Printers of the Mind' and Other Essays (ed. P. D. McDonald and M. F. Suarez, S.J.; Amherst/Boston: University of Massachusetts Press, 2002) 198-236. See also R. Chartier, Forms and Meanings: Texts, Performances, and Audiences from Codex to Computer (Philadelphia: University of Pennsylvania Press, 1995). 
Notes on the Epistles of St Paul (1705-7). In his attempt to discern the coherence of Paul's thought in his major letters, Locke found himself immediately thwarted by the chapter and verse divisions found in modern Bibles, which, he alleged, 'crumbled' Paul's unified compositions 'into broken and incoherent aphorisms':

First, the dividing of them into Chapters and Verses, as we have done, whereby they are so chop'd and minc'd, and as they are now Printed, stand so broken and divided, that not only the Common People take the Verses usually for distinct Aphorisms, but even Men of more advanc'd Knowledge in reading them, lose very much of the strength and the force of the Coherence ... ${ }^{3}$

Despite Locke's best efforts to read the letters from beginning to end in single sittings and without regard for the artificial divisions in thought created by chapters and verses, he still retained the chapter and verse system in his work and frequently cited and cross-referenced the letters in this 'chop'd and minc'd' fashion. The advantages of this technology were simply too tempting for even him to resist.

While Locke was wise to worry about how the form in which we read Paul's letters shapes how we comprehend them, he was incorrect to presume that the division of the Bible into chapters and verses was unique to his age. Although verse divisions as we know them were not introduced until the mid-sixteenth century, ${ }^{4}$ Christians began experimenting with novel forms of textual division almost as soon as they broke with cultural norms in their preference for the codex in place of the scroll. ${ }^{5}$

By the mid-fourth century Christian scholars had established their place as the leading innovators of manuscript technology in the Roman world, and nowhere was this more evident than in their adoption of the codex and their exploratory

2 Appendix Iv: 'Difficulties in St Paul's Epistles' in J. Locke, A Paraphrase and Notes on the Epistles of St Paul to the Galatians, 1 and 2 Corinthians, Romans, Ephesians (2 vols.; ed. A. W. Wainwright; Oxford: Clarendon, 1987) II.673.

3 Locke, A Paraphrase and Notes on the Epistles, I.105. Locke may be envisioning the typographical convention found in translations such as the Geneva Bible and the King James Version, which indent each verse as though it was a new paragraph. In the KJV actual paragraph divisions are marked by the pilcrow sign $(\boldsymbol{\Upsilon})$.

4 This is the innovation of the printer Robert Stephanus (Estienne) (1551). His Greek and Latin edition with verses became the basis for the Geneva Bible, which was the first translation to use Stephanus' verse divisions. Stephen Langton (d. 1228) is usually credited with establishing modern chapter divisions.

5 On this transition, see esp. L. W. Hurtado, The Earliest Christian Artifacts: Manuscripts and Christian Origins (Grand Rapids/Cambridge: Eerdmans, 2006) 43-93; H. Y. Gamble, Books and Readers in the Early Church: A History of Early Christian Texts (New Haven: Yale University Press, 1995) 42-81. 
use of new systems for textual division and cross-referencing. ${ }^{6}$ As Jason König and Tim Whitmarsh have noted, 'It is surely no coincidence that the earliest codices contained Christian and technical material, two genres of discourse that privilege, indeed insist upon, cross-referencing and non-linear reading. ${ }^{7}$ The technological advantages of the codex's pagination, which allows a reader to range horizontally across a corpus at random access points, certainly stimulated Christian experimentation with editorial apparatuses. ${ }^{8}$ The pinnacle of ancient Christian innovation in this regard is Eusebius of Caesarea's Canons for the fourfold Gospel, a work of revolutionary philological scholarship that anticipates modern gospel criticism by nearly 1,500 years. ${ }^{9}$ By exploiting the numerical simplicity of a marginal apparatus to organise the complex data of gospel parallels, Eusebius' Canons demonstrate the enormous intellectual potential of citation systems for scholarly work on literary texts. As a conceptual forerunner of the modern Synopsis and gospel criticism, Eusebius' work also exhibits the interconnectedness of reading technologies with intellectual developments.

Not long after the completion of Eusebius' Canons, Priscillian of Avila, probably in the second half of the fourth century, produced a work on the Pauline corpus of comparable technological ingenuity and theological originality. Although Priscillian's Canones Epistularum Pauli Apostoli and its accompanying edition of the Pauline corpus remain largely unknown today to Pauline scholars and certainly under-studied, his Pauline Canons nonetheless represent for modern Pauline scholarship what Eusebius' Canons do for modern Synoptic criticism: an innovation both in ancient book technology and in theological scholarship. Priscillian's state-of-the-art use of editorial devices for organising textual knowledge in codex form and his unique system for synthesising Pauline theology also anticipate modern developments. But more than merely anticipating them, what we observe in Priscillian's work is the critical role that structures for precise citation and cross-referencing play in the systematic arrangement of Pauline data into an interrelated whole. In other words, what we observe in his

6 On these developments, see the elegant study by A. Grafton and M. Williams, Christianity and the Transformation of the Book: Origen, Eusebius, and the Library of Caesarea (Cambridge, MA: Harvard University Press, 2006).

7 J. König and T. Whitmarsh, 'Ordering Knowledge', Ordering Knowledge in the Roman Empire (ed. J. König and T. Whitmarsh; Cambridge: Cambridge University Press, 2007) 3-39, at 34.

8 The advantages of the codex are sometimes extolled as though the scroll offered no distinct advantages of its own. For reflections on the advantages of both, see G. Cavallo, 'Between Volumen and Codex: Reading in the Roman World', A History of Reading in the West (ed. G. Cavallo and R. Chartier; trans. L. G. Cochrane; Amherst: University of Massachusetts Press, 1999) 64-89, esp. 83-9. See also Gamble, Books and Readers, 49-66.

9 See M. R. Crawford, 'Ammonius of Alexandria, Eusebius of Caesarea and the Origins of Gospels Scholarship', NTS 61 (2015) 1-29. 
work is the inextricable link between technologies for reading a text and that text's hermeneutical potential.

\section{Defining Pauline Theology}

To designate Priscillian's work a precursor of the modern discipline of Pauline theology requires some definition of the latter. ${ }^{10}$ Today 'Pauline theology' frequently refers to analyses of Paul's thinking on particular theological (or even non-theological) subjects. To speak of Paul's theology of $x, y$, or $z$ is thus to speak of the ways in which Paul treats $x, y$, or $z$ as theological loci. Such considerations often correspond to the contingent dimension of Pauline theology, to evoke Beker's classic distinction, ${ }^{11}$ and sometimes belong to the first phase of a larger theological undertaking. 'Pauline theology' also then refers to that larger theological undertaking, which is the attempt to draw together an entire system or, for some, a core of Paul's total theological thinking. This form of Pauline theology is usually expressed in terms of ultimate coherence or systemisation and involves the comprehensive presentation of Pauline data (though usually epistolary data alone). ${ }^{12}$ As James Dunn puts it, 'a theology of Paul cannot be more than the sum of the theology of each of the individual letters, and yet it has to be more than simply the sum of the letters' theologies'. ${ }^{13}$ What Dunn's paradox names is the fact that, although Pauline theology is in some sense the aggregate of Pauline epistolary parts, the ordering and synthesis of those parts remains the handiwork of an interpreter who is doing theology every bit as much as she or he is reconstructing it. Since Pauline theology, like all theology, is 'a secondorder discipline dependent on the first-order language', ${ }^{14}$ the personality of the theologian cannot be disentangled from the theological procedure.

The first challenge in composing a Pauline theology in the comprehensive sense is to determine the systemic foundation on which to organise it. ${ }^{15} \mathrm{~A}$

10 The following definition is not envisioned as encompassing every thinker who has ever had an interest in the subject, but rather it attempts to articulate broad parameters within which most scholars would locate themselves.

11 J. C. Beker, Paul the Apostle: The Triumph of God in Life and Thought (Philadelphia: Fortress, $1984[1980])$.

12 For analysis of the ways in which contingency, coherence and systemisation (or lack thereof) have been approached in recent Pauline scholarship, see D. A. Campbell, Framing Paul: An Epistolary Biography (Grand Rapids: Eerdmans, 2014) 1-10.

13 J. D. G. Dunn, The Theology of Paul the Apostle (Grand Rapids: Eerdmans, 1998) 14.

14 H. W. Frei, Theology and Narrative: Selected Essays (ed. G. Hunsinger and W. C. Placher; New York: Oxford University Press, 1993) 96.

15 So Dunn: 'If we can speak about the theology of Paul, and not just his doctrine or religion or rhetoric, and about the theology of Paul, and not just the theology of his letters, that still leaves us with the question: How to go about writing that theology?' (Theology of Paul the Apostle, 19; emphasis original). 
Pauline theology requires an order or grounding, but since the letters do not explicitly deliver this, it has to be extrapolated. One traditional way of organising Paul's theology in modern scholarship is on the basis of Romans. This approach recalls Phillip Melanchthon's Loci communes (1521) and is adopted by Dunn and others prior to him. ${ }^{16}$ Like Melanchthon's great work, which attempts to systematise the whole of Christian teaching on the basis of the structure of Romans, this approach to Pauline theology takes the argumentative construction of Romans (or its supposed argumentative construction) as scaffolding upon which to coordinate the rest of the epistolary data. The presumption underwriting this approach is that Romans represents Paul's most systematic presentation of his thought (a 'compendium of Christian doctrine', as Melanchthon would have it), and therefore it offers the most reliable template for organising his theology in systematic terms. ${ }^{17}$

Priscillian's approach, though differing in its organising principle, still corresponds with the modern procedure in that he uses an independently derived structure for presenting Paul's thought. For Priscillian that structure is, very broadly, the shape of the Old Roman Creed (i.e. the Apostle's Creed), a tradition to which he and Marcellus of Ancyra are our earliest witnesses. ${ }^{18}$ Priscillian's first eleven canons thus concern Pauline thinking about God and God's relation with the world. Canons 12 to 20 concern the person of Christ, and then canon 21 the Holy Spirit. From canon 22 onwards Priscillian treats numerous subjects, such as the problem of sin and the effects of salvation, various ethical and ecclesial matters, and then specific issues related to the biography and teaching of Paul (canons 61-78), especially his teaching on the Law (canons 64-70). The canons then conclude in 82-90 with nine propositions regarding the 'general resurrection $^{\prime 19}$ and then the final judgement and eternal destiny of the righteous - in other words, 'the resurrection of the body, and the life everlasting'. ${ }^{20}$

16 A more recent and alternative (and especially elaborate) approach to ordering Pauline theology is that of N. T. Wright, who begins his Paul and the Faithfulness of God (London: SPCK, 2013) straightaway with a 'map' of the book's contents. Wright plots Paul's theology in four major parts, which comprise sixteen chiastically arranged chapters. 'Paul's Mindset' (Part II) and 'Paul's Theology' (Part III) stand at the pinnacle of Wright's chiasm.

17 This view has, of course, been severely criticised and only a minority of scholars today would endorse anything resembling it.

18 We find this creed or symbolum reproduced and discussed in Priscillian's Second Tractate. See T. Toom, 'Marcellus of Ancyra and Priscillian of Avila: Their Theologies and Creeds', VC 68 (2014) 60-81.

19 In canons 82-4 he appears to follow Paul (but not the 'Paul' of Acts 24.15) in focusing on the implications of Christ's resurrection for the resurrection of the saints.

20 As for the theological profile of the Canons, there is a pervasive emphasis on dualism, especially between God and world, flesh and Spirit, the righteous and the wicked. There is also heavy emphasis on God's impending day of judgement. Priscillian's Paul thus expresses a great deal of apocalyptic urgency, as apparently did Priscillian himself. 
What makes Priscillian's work so curious - and so intriguing - is the fact that the enterprise of organising Pauline data into a structured Pauline theology is otherwise a decidedly modern endeavour. In other words, the scholarly study of Paul represented by his Canons is without precedent and without successor for well over 1,000 years. Albert Schweitzer traced the modern interest in a Pauline 'system of thought' to early nineteenth-century German-speaking scholarship. He appointed the Swiss theologian Leonhard Usteri's work, The Development of the Pauline System of Doctrine (1824), as 'the starting-point of the purely historical study of Paulinism'. ${ }^{21}$ Schweitzer is certainly correct about the modern innovation of 'purely historical' Pauline research. But he is also correct about the interest in 'Paulinism', or a Pauline 'system of theology', as a characteristic feature of modernity. Ancient authors certainly interacted with Pauline theology in many modes - as in the case of Pauline pseudepigrapha, or Pauline commentary, or Acts and other biographical traditions, or every scribe or patron involved with a Pauline manuscript - but they did not compose theologies of Paul in the sense in which Paul's theology is regarded as a subject in its own right. One simply does not find ancient treatises with titles along the lines of On the Theology of St Paul. Except in the case of Priscillian.

\section{Priscillian of Avila and his Canons on the Letters of the Apostle Paul}

The most famous and secure fact about Priscillian is that he was executed in the mid 380 s in the German town of Trier (Augusta Treverorum). A former Spanish bishop and already censured heretic, Priscillian stood trial before the Christian emperor Maximus for, among other things, cavorting with women and engaging in sorcery (the latter was a capital offence). Upon his conviction he was executed, and so the ancient heresy of Priscillianism was born. ${ }^{22}$ Prior to 1886, when eleven lost Priscillianist tractates were discovered by Georg Schepss in the University of Würzburg library, all that remained of this Spanish heretic besides his infamy was his surprisingly influential Canones Epistularum Pauli Apostoli. ${ }^{23}$ Composed sometime in the second half of the fourth century,

21 A. Schweitzer, Paul and his Interpreters: A Critical History (trans. W. Montgomery; London: Adam and Charles Black, 1912) 9.

22 For a succinct introduction to Priscillian's life and work, see M. Conti, Priscillian of Avila: The Complete Works (Oxford: Oxford University Press, 2010) 1-29. His Canons on the Letters of the Apostle Paul are briefly noted in H. A. G. Houghton, The Latin New Testament: A Guide to its Early History, Texts, and Manuscripts (Oxford: Oxford University Press, 2016) 20, 202.

23 In fact, a series of anonymous Priscillianist prologues for the Gospels had also been passed down in the Vulgate tradition (on which see more below), but these were only recognised as deriving from Priscillian's movement after the discovery of the Würzburg tractates. 
the work is extant in twenty-two Vulgate manuscripts ranging from the ninth to the fifteenth century - and this despite Priscillian's reputation as a heretic. ${ }^{24}$ It even remained influential up until the Renaissance, when it was imitated by Jacques Lefèvre d'Étaples (Jacobus Faber Stapulensis). ${ }^{25}$ The editio princeps, based on Codex Cavensis (ninth century), was published in 1843 by Angelo Mai. ${ }^{26}$ Other editions informed by additional manuscripts include those of Schepss, ${ }^{27}$ Wordsworth and White ${ }^{28}$ and De Bruyne. ${ }^{29}$ An English translation of the entirety of Priscillian's corpus has now been provided by Marco Conti. ${ }^{30}$

The work as we now know it in the extant Vulgate traditions comprises three parts: (1) two introductory prologues - one by a Bishop Peregrinus and another by Priscillian himself; (2) the ninety 'canons', which are discrete propositional statements of Pauline theology with a list of supporting citations from the letters themselves; and (3) Priscillian's edited version of the fourteen Pauline letters (with the addition of Hebrews). Most important about this edition is that it includes Priscillian's novel paratextual system, which divides each letter into numbered testimonies (testimonia) - or we might say verses - for purposes of citation. ${ }^{31}$ He also appends the corresponding canon numbers, where they exist, next to the testimonia numbers to cross-reference the Pauline data with his theological summations.

The Canons are preceded in all extant versions first by a preface from an otherwise unknown Bishop Peregrinus, who explains that although the canons have been affixed to Jerome's Vulgate, Jerome is not their author. ${ }^{32}$ Peregrinus $^{2}$

24 For a brief description of several of these manuscripts that preserve the canons, see Houghton, Latin New Testament, 249, 267, 277, 280. On Codex Cavensis, see p. 255.

25 I. Backus, 'Jacques Lefèvre d'Étaples: A Humanist or a Reformist View of Paul and his Theology?', A Companion to Paul in the Reformation (ed. R. W. Holder; Leiden: Brill, 2009) 61-90, esp. 76-81.

26 A. Mai, Spicilegium Romanum, vol. Ix (Rome, 1843) 744-63.

27 G. Schepss, Priscilliani quae supersunt (CSEL 18; Vienna, 1889) 109-47.

28 J. Wordsworth and H. J. White, Novum Testamentum Domini Nostri Iesu Christi Latine secundum editionem Sancti Hieronymi, vol. II/1 (Oxford, 1913) 17-32.

29 D. De Bruyne, Préfaces de la Bible latine (Namur, 1920) 224-34.

30 Conti, Priscillian of Avila. An English translation of the Canons is also offered by V. Blomkvist, Euthalian Traditions: Text, Translation and Commentary (TUGAL 170; Berlin: de Gruyter, 2012) 255-69. Blomkvist does not, however, provide Priscillian's Pauline references.

31 For Priscillian's use of the term testimonium in this regard, see n. 56.

32 For discussion of the identity (or perhaps pseudonymity) of this Peregrinus, see H. Chadwick, Priscillian of Avila: The Occult and the Charismatic in the Early Church (Oxford: Clarendon, 1976) 59-60. Houghton, Latin New Testament, 62-3, suggests that a century after Priscillian, there was a further Spanish edition of biblical writings that drew upon both Jerome and Priscillian, including the revised Priscillian canons. In Houghton's estimation, the identity of this reviser is 'unclear', though portions of the new Spanish edition, such as the revision of Proverbs and the revised canons, are attributed to a Bishop Peregrinus. 
identifies Priscillian as the author but then assures the reader that, though a heretic, Priscillian's Canons are still full of many indispensable things and any trace of heresy has been dutifully corrected. ${ }^{33}$ After Peregrinus' remarks comes Priscillian's own introduction, which describes his method of textual division and explains how to read the Canons in relation to his cross-referencing system. Priscillian's introduction is presented as a personal response to an unidentified confidant who had asked him to provide a simple defence, or bulwark (propugnaculum), ${ }^{34}$ against the deceits of heretics. Priscillian explains that he has decided to focus his efforts on the 'scriptures set in the middle', by which he means 'the fourteen letters of the most blessed Paul the Apostle'. He explains that he first determined 'to distinguish the meanings of the testimonies in their text' (in earum textu sensus testimoniorum distinguere). The verb distinguo can also, in rhetoric and grammar, mean 'to divide' or 'to punctuate' or even 'to mark pauses in a discourse', which is how Priscillian is using it here to describe his philological project. ${ }^{35}$ As Priscillian goes on to explain, he has 'distinguished' or 'divided' the sense or meaning of the testimonia by numbering them in black ink beginning with one and continuing until each letter's end.

With this citation system in place Priscillian next began composing his canons. As Priscillian explains, the canons are numbered one (I) to ninety (xc), but in red ink instead of black. He also notes that the canons are intended to convey the 'flavour' (sapor) or essence of the testimonies, and he indeed sticks closely to keywords in the letters, even as he recombines them. Below each canon are then listed the citations from the letters that supply the 'flavour' for Priscillian's theological propositions. The first canon illustrates Priscillian's procedure: ${ }^{36}$

33 So Chadwick notes, 'A reading of the ninety canons shows that Peregrinus corrected well; the text contains nothing heretical. At the same time the veil concealing the original Priscillian often seems diaphanous' (Priscillian of Avila, 6o).

34 Latin citations follow Schepss, Priscilliani quae supersunt.

35 Lewis \& Short, s.v. distinguo I $(\alpha)$.

36 The references under the English translation represent the equivalent in modern versification. For a key to these correspondences, see Schepss, Priscilliani quae supersunt, 169-74. Also newly available is Donatien De Bruyne's important work, Sommaires, divisions et rubriques de la Bible latine (Namur: Auguste Godenne, 1914), now reprinted (with an English title and new introductions by M. Bogaert and T. O'Loughlin) as Summaries, Divisions and Rubrics of the Latin Bible (Studia Traditionis Theologiae 18; Turnhout: Brepols, 2015). For the coordination of Priscillian's divisions and other Latin textual divisions with modern versification, see pp. 527-49. 


\begin{tabular}{|c|c|}
\hline $\begin{array}{l}\text { Can. I. Deus verax est, spiritus quoque } \\
\text { deus et deus saeculorum possidens } \\
\text { inmortalitatem estque invisibilis lucem } \\
\text { habitans inaccessibilem, rex etiam atque } \\
\text { dominus, cuius est imago ac } \\
\text { primogenitus Christus, in quo non } \\
\text { invenitur 'est et non', sed 'est' } \\
\text { tantummodo. }\end{array}$ & $\begin{array}{l}\text { Canon 1. God is true, and God is also } \\
\text { Spirit and God of the ages, possessing } \\
\text { immortality, and is invisible, dwelling } \\
\text { in inaccessible light, King and also } \\
\text { Lord, whose image and firstborn is } \\
\text { Christ, in whom 'yes and no' is not } \\
\text { found but 'yes' alone. }\end{array}$ \\
\hline Rom. 18. & Rom 3.1-4 \\
\hline Cor. II. 6. 18. 22. & $\begin{array}{l}2 \text { Cor } 1.18-20 ; 3.17-17 \text { [ubi]; } 4.2 \text { [ad. om. } \\
\text { cons.]-4.4[qui est] }\end{array}$ \\
\hline Col. 5. & Col 1.15-16 \\
\hline Tim. I. 5. (11.) 28. 29. & 1 Tim $1.12-16 ; 2.8-10 ; 6.6-12 ; 6.13-16$ \\
\hline Titus 1. & Titus 1.1-4 \\
\hline Hebr. 1. 11. 18. 19. & $\begin{array}{l}\text { Heb } 1.1-4 ; 6.11-7.17 ; 10.19-34 ; 10.35^{-} \\
11.35 \text { [mort. suos] }{ }^{37}\end{array}$ \\
\hline
\end{tabular}

The numbering of the ninety canons is important because throughout his edition of the letters Priscillian has also incorporated the canon numbers, where they exist, next to whichever testimonies are cited. This completes the circle on the cross-referencing scheme. One can read Priscillian's work from the canonical synthesis back to the Pauline data or from the Pauline data to the canonical synthesis. One can read all the citations in a given canon in relation to one another, or trace how a given passage is used in various canons. The relationship between the canonical proposition and the citations supporting it is, therefore, mutually reinforcing. The references supply the raw material for the theological synthesis, but the synthesis also informs how those texts are then read individually and in relation to one another. As Chadwick notes, this unique combination of dogmatic Pauline propositions with accompanying citations from the letters is 'designed to give the reader a coherent picture of what Priscillian thinks central in Pauline theology'. ${ }^{38}$ It is, indeed, an ambitious attempt to construct a comprehensive account of Pauline theology, but it is also much more than this. Although Priscillian's ingenious technology for coordinating primary textual knowledge with secondary theological synthesis remained without parallel for over a millennium following, the technological and theological

37 The words in brackets mark where a testimonium begins or ends in Priscillian's division of the text.

38 Chadwick, Priscillian of Avila, 59. 
principles that animated Priscillian's work have become foundational elements in modern scholarship. ${ }^{39}$

Priscillian's normal practice in dividing the Pauline letters is to 'distinguish' testimonia in what amounts to anywhere between two and four modern verses although sometimes much less, sometimes much more. Table 1 illustrates the number of testimonia into which each letter is divided, as well as how many times material from each letter is used in the Canons. Priscillian usually divides according to what he takes to be reasonable sense units or where he sees structural or thematic shifts. The one letter that most frequently departs from this typical practice is Hebrews. Some testimonia, such as testimonium 19 in Hebrews, approach chapter length according to modern standards (Heb 10.35-11.35[suos]), while others, such as testimonium 20 in Hebrews, are little more than half a modern verse (Heb 11.35[alii]-11.35[resurrectionem]). The use of much smaller divisions is not, however, unique to Hebrews, and it appears to occur in expressions for which Priscillian has specific purposes, or in ones that involve stark contrasts, which he then divides into discrete propositions. It seems that his approach to division was from the outset motivated by his plan to cite the various testimonia in his larger theological synthesis.

In an age accustomed to information technology like book division, versification, indexes and tables of contents, it is important to underscore the ingenuity of Priscillian's Canons as the earliest extant index keyed to a literary corpus by means of a numerical system. Nothing prior to Priscillian's Canons approaches this degree of technological sophistication. Although the novelty of his system should not be overlooked, aspects of his apparatus were not without precedent.

39 Images of Priscillian's Canons and of his textual division of the beginning of Romans in Codex Cavensis are available at the following links. These are published with the permission of the Biblioteca del Monumento Nazionale Badia di Cava. The first image is of Codex Cavensis, fol. 253r: https://www.academia.edu/29472144/Codex_Cavensis_fol._253r. The first two columns contain the two introductory prologues to the canons; the list of canons begins at the bottom of the middle column and continues in the third column, numbered consecutively in the margin, with a red $\mathrm{k}$ for kanon before each canon number, also in red. The second image is of Codex Cavensis, fol. 255v: https://www.academia.edu/29472100/Codex Cavensis_fol._255v. The text of Romans begins at the top of the third column, with Priscillian's testimonia numbered consecutively in the left margin in black, and the corresponding canon number beneath in red, marked in each instance by a leading $\mathrm{k}$ followed by the Roman numeral. Note also the use of small red sloping lines in the space between the lines of biblical text to denote the specific portion of each testimonium that is relevant to the canon listed in the margin. 


\section{Paratexts in Antiquity}

Since the work of the literary theorist Gérard Genette, it has become common to refer to textual devices such as titles, prefaces and tables of contents as 'paratexts'. ${ }^{40}$ As Genette remarks, a text

is rarely presented in an unadorned state, unreinforced and unaccompanied by a certain number of verbal or other productions, such as an author's name, a title, a preface, illustrations. And although we do not always know whether these productions are to be regarded as belonging to the text, in any case they surround it and extend it, precisely in order to present it, in the usual sense of the verb but also in the strongest sense: to make present, to ensure the text's presence in the world, its 'reception' and consumption in the form (nowadays, at least) of a book..$^{41}$

Hence, although a paratext is not a part of the text proper, it is indispensable to the text as a 'threshold'42 that conditions a reader's expectations for the work to follow. Paratexts are, then, not superfluous adornments to the text. They are instead integral to it and affect any reading of it, even if only in subliminal ways. As Laura Jansen puts it, 'Far from being an issue that preoccupies only the theoretically minded, the matter of the paratext is always - albeit often imperceptibly - already at work in the hermeneutic process. ${ }^{43}$

The study of ancient paratexts is a fairly recent development, but one that is quickly progressing along multiple avenues of investigation. ${ }^{44}$ In 2011 the

40 G. Genette, Paratexts: Thresholds of Interpretation (trans. Jane E. Lewin; Literature, Culture, Theory 20; Cambridge: Cambridge University Press, 1997).

41 Genette, Paratexts, 1.

42 Genette, Paratexts, 2.

43 L. Jansen, 'Introduction: Approaches to Roman Paratextuality', The Roman Paratext: Frame, Texts, Readers (ed. L. Jansen; Cambridge: Cambridge University Press, 2014) 1-18, at 1.

44 The reason for prior neglect can be attributed in part to the propensities of Protestant scholarship, which has by and large viewed ancient paratextual material in Greek and Hebrew manuscripts as accretions to be discarded in order to recover the text itself, the true site of God's revelation. As a result, inattention to this material is a major lacuna in most modern critical editions. See esp. T. O'Loughlin, 'De Bruyne's Sommaires on its Centenary: Has its Value for Biblical Scholars Increased?', Summaries, Divisions and Rubrics of the Latin Bible, xix-xxvi. As O'Loughlin notes, for Roman Catholic scholars committed to the Vulgate, 'the sacred text, for all its problems, did not come alone but was embedded within a web of other material: various ways of gathering books together, lists of chapter headings, a variety of division systems, cross-referencing systems, along with aids to readers which, starting with the work of Eusebius of Caesarea, seemed to have been added to by every generation until the time of printing' (p. xx). Because for Catholic scholars the work of the Spirit is not restricted to a single moment of biblical revelation, 'the tradition was part of the work of the Spirit speaking in the Church and it was to be respected as such ... By culture, training, and temperament the Vulgate editors were inclined to value everything they found in a codex: it was, in its totality, part of the tradition' (p. xxi). A notable exception to the trend of Protestants overlooking 
Table 1. Epistolary Data in Priscillian's Canons

\begin{tabular}{|c|c|c|c|}
\hline Pauline Letter & $\begin{array}{c}\text { No. of } \\
\text { testimonia in } \\
\text { each letter }\end{array}$ & $\begin{array}{l}\text { No. of letter } \\
\text { references in } \\
\text { Prisc. Can. }\end{array}$ & $\begin{array}{c}\text { No. of canons in } \\
\text { which the letter } \\
\text { appears }\end{array}$ \\
\hline Romans & 125 & 243 & 66 \\
\hline 1 Corinthians & 105 & 184 & 57 \\
\hline 2 Corinthians & 61 & 105 & 44 \\
\hline Galatians & 38 & 72 & 27 \\
\hline Ephesians & 41 & 96 & 45 \\
\hline Philippians & 25 & 43 & 26 \\
\hline 1 Thessalonians & 22 & 45 & 26 \\
\hline 2 Thessalonians & 10 & 21 & 14 \\
\hline Colossians* & 34 & 74 & 43 \\
\hline 1 Timothy & 31 & 62 & 32 \\
\hline 2 Timothy & 26 & 49 & 25 \\
\hline Titus & 15 & 26 & 17 \\
\hline Philemon & 5 & 6 & 5 \\
\hline Hebrews & 28 & 112 & 52 \\
\hline Total & 566 & 1138 & \\
\hline
\end{tabular}

*This is where Priscillian has located Colossians in his edition of the letters. Priscillian is not alone in placing Colossians here. See E. Harrison Lovering, Jr, 'The Collection, Redaction, and Early Circulation of the Corpus Paulinum' ( $\mathrm{PhD}$ diss., Southern Methodist University, 1988), esp. 259-62.

University of St Andrews hosted a conference that resulted in a collection of essays published in 2014 under the title The Roman Paratext, and in 2015 a four-year project funded by the European Research Council began, with the aim of cataloguing more than 500 biblical paratexts from more than 2,500 Greek

paratexts is Eberhard Nestle, who was enthusiastic about the Eusebian canons. See his 'Die Eusebianische Evangelien-Synopse', Neue Kirchliche Zeitschrift 19 (1908) 40-51, 93-114, 219-32. 
manuscripts. ${ }^{45}$ Isolated studies of biblical paratexts have recently appeared and more are sure to follow. ${ }^{46}$ Yet so far Priscillian's important contribution to this literary form has been entirely overlooked.

The use of paratexts in ancient literature corresponds to the developing interest in systems for dividing texts into discernible units and then in more precise systems for citing portions of a text. In an illuminating article Carolyn Higbie has traced the development of ancient citation conventions from the Hellenistic through to the Roman period. In the oldest form, authors were cited simply by name or by name and work, though occasionally a specific scene or subject was also mentioned. ${ }^{47}$ Aristotle is a characteristic example of the more specific form of citation (Poetics 1454b):

Clearly the denouement of a plot should follow from the plot as such, and not from a contrivance as in Medea and the episode of departure in the Iliad.

Here Aristotle is referring to Euripides' Medea 1317 and Iliad 2.155. Since those texts did not originally have any ordered divisions or features that could be cited, this is as precise as his reference can be. In time numbered textual divisions were added to works like those of Homer and Euripides, and these were then used for purposes of citation, but this only occurred centuries after the original compositions. In 99 вСе, for instance, the Lindian Chronicle refers to the second book of Herodotus' Histories: 'About which Herodotus the Thurian testifies in the second

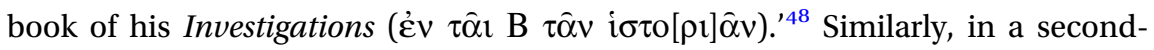
century CE papyrus, the second-century BCE scholar Apollodorus of Athens is

45 M. Wallraff and P. Andrist, 'Paratexts of the Bible: A New Research Project on Greek Textual Transmission', Early Christianity 6 (2015) 237-43. More information can be found on the project's website at www.paratexbib.eu/index.html (accessed 1 July 2015). The project intends to publish an online e-Clavis of all the paratexts studied, which will surely facilitate further research on these traditions.

46 Cf. A. A. den Hollander, U. Schmid and W. F. Smelik, eds., Paratext and Megatext as Channels of Jewish and Christian Traditions: The Textual Markers of Contextualization (Jewish and Christian Perspectives Series 6; Leiden: Brill, 2003); Blomkvist, Euthalian Traditions; P. S. Alexander, A. Lange and R. Pillinger, eds., In the Second Degree: Paratextual Literature in Ancient Near Eastern and Ancient Mediterranean Culture and its Reflections in Medieval Literature (Leiden: Brill, 2010); S. J. Gathercole, 'The Titles of the Gospels in the Earliest New Testament Manuscripts', ZNW 104 (2013) 33-76; Crawford, 'Ammonius of Alexandria, Eusebius of Caesarea and the Origins of Gospels Scholarship'; D. Lincicum, 'The Paratextual Invention of the Term "Apostolic Fathers"', JTS 66 (2015) 139-48.

47 C. Higbie, 'Divide and Edit: A Brief History of Book Divisions', Harvard Studies in Classical Philology 105 (2010) 1-31, at 3-4. The references to Homer in Herodotus' Histories 2.116 and in Thucydides' History 1.9.4 and 1.10.4 are good examples of this style, which noticeably lacks any mention of enumeration, or even book division. These are cited and discussed in Higbie, 'Divide and Edit', 4-7.

48 Cited in Higbie, 'Divide and Edit', 9. 
said to have written a commentary on 'book 14' of the Iliad (see Pap. Med. 19 $\left[=\right.$ Pack $^{2}$ 1197] $) .{ }^{49}$ These are the earliest extant references to Homer and Herodotus being cited by book division.

While the earliest forms of book division were later editorial supplements to previously undivided texts, the historian Ephorus (fourth century ${ }_{\mathrm{BC}}$ ) was perhaps the first author to use book division as a compositional principle, ${ }^{50}$ and in this he was followed by his fellow historian Polybius (second century вСЕ). ${ }^{51}$ The earliest surviving tables of contents in Latin date to shortly after this time. ${ }^{52}$ From around the first century вСЕ onward, book division became more common and, accordingly, authors began citing works by book number more frequently. Cicero and Quintillian are prominent examples among Latin authors who from the outset of composition structured the content of their works by book, but the author who made the most extensive use of this device was Pliny the Elder. He in fact devoted the entirety of the first book of his thirty-six-book Natural History to a table of contents for the work that follows. ${ }^{53}$ His adopted nephew Pliny the Younger may have been deliberately following his uncle when he prepared his edition of his own letters, for he too began each of the nine books of his collection with a table of contents listing the addressees and incipits for each letter. ${ }^{54}$ By the third century CE, citation by book number was more frequent, as seen, for example, in Athenaeus, who cited numerous authors, and not just the likes of Homer and Herodotus, by book number. As Higbie notes, this third-century evidence 'suggests an increasingly literate world, in which writers consult texts and provide citations for their readers' ${ }^{55}$ The degree to which paratextual navigation was being used by the early fifth century can be seen in the acta from the Council of Carthage held in 411. In his preface to the minutes of the council, the notary Marcellus explained that he included an enumerated table of contents as a 'shortcut' (conpendium) to enable readers to find quickly what they were searching for, and the subsequent list of capitula runs to forty-six pages in the critical edition of the text, comprising 882 headings. $^{56}$

49 Higbie, 'Divide and Edit,' 10.

50 So Diodorus Siculus remarks that Ephorus 'constructed each of his books to encompass events according to subject' (The Library of History, 5.1.4).

51 Higbie, 'Divide and Edit', 16-19.

52 See A. M. Riggsby, 'Guides to the Wor(1)d', Ordering Knowledge, 88-107. Riggsby points out that 'there are no indices in classical Roman texts', and that the earliest mentioned Latin table of contents is that of Q. Valerius Soranus, whom Pliny the Elder presents as a precedent for his usage of the literary form (89-90). Riggsby then examines in detail the tables of contents of Scribonius Largus, Pliny, Columella and Aulus Gellius. As he argues, the fact that all four authors feel the need to justify the inclusion of this device is further evidence of its rarity.

53 Riggsby, 'Guides to the Wor(1)d', 24-6.

54 R. Gibson, 'Starting with the Index in Pliny', Roman Paratext, 33-55.

55 Higbie, 'Divide and Edit', 27.

56 See Marcelli Praefatio in S. Lancel, ed., Gesta conlationis Carthaginiensis, anno 411 (CCSL 149A; Turnhout: Brepols, 1974) 4-52. We are grateful for the help of Alden Lee Bass who 
Hence, by the time Priscillian was writing in the late fourth century, the division of a sufficiently lengthy work into a series of enumerated sections was relatively common, but what sets his innovation apart from those already discussed is that he divided the Pauline corpus not into 'books' (libri; $\beta i ́ \beta \lambda o 1)$ or 'chapters' (ca-

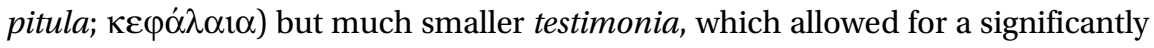
more precise citation system. The identification of individual scriptural prooftexts as testimonia had been going on for at least a century in the Latin West, ${ }^{57}$ and it is likely that the impetus for Priscillian's project also was the selection of useful proof-texts for theological debate, as he himself indicates in his preface. Yet by sectioning and enumerating not merely isolated passages, but instead each Pauline letter in its entirety from beginning to end, he created a comprehensive citation system with utility exceeding the original design of its author. In this respect he was probably following a path blazed by an earlier fourth-century author, Eusebius of Caesarea.

\section{Ancient Christian Paratexts, Priscillian's Pauline Canons and Eusebius' Gospel Canons}

Paratexts for the books that would eventually become the New Testament were first developed as early as the second century with a series of prologues to the Pauline letters that may go back to Marcion's edition of the Corpus Paulinum. ${ }^{58}$ The fourth century, however, seems to have been a period of particularly intense development of this genre, with the most prominent example being

pointed us to this source, and to Adam Ployd who assisted us in accessing it. In the preface, the notary Marcellus also defended his table of contents against those who regarded it as a waste of time. However, rather than being a sign of the novelty of the paratextual device at the time, Marcellus' defensive tone is surely due to the unusually large proportions of his table of contents.

57 The most prominent example is Cyprian's treatise titled Ad Quirinum testimoniorum libri III. This work is almost entirely a series of proof-texts (testimonia) from scripture gathered under topical headings. The first book deals with the relation of Christianity to Judaism, the second with Christology, and the third with Christian virtue. The format of Priscillian's Canons closely follows that of Cyprian, with thesis statements functioning as headings under which relevant Pauline passages are compiled. What distinguishes the two is that Priscillian's is an attempt to focus exclusively on Paul and to do so comprehensively. Cyprian's Ad Quirinum exerted significant influence on the later Latin tradition, including authors such as Lactantius, Firmicus Maternus, Lucifer of Cagliari, Jerome, Pelagius and Augustine (J. Quasten, Patrology, vol. II (Notre Dame, IN: Christian Classics, n.d.) 363), so it is reasonable to suppose that Priscillian might also have seen the treatise and been directly influenced by its format.

58 See N. A. Dahl, 'The Origin of the Earliest Prologues to the Pauline Letters', Studies in Ephesians: Introductory Questions, Text- and Edition-Critical Issues, Interpretation of Texts and Themes (ed. D. Hellholm, V. Blomkvist and T. Fornberg; Tübingen: Mohr Siebeck, 
the Eusebian Canons, which were translated into Latin in the early 380 s and passed to the Latin world along with Jerome's Vulgate edition. There is also at this time widespread evidence for the division of biblical books into chapters, known in Greek as $\kappa \varepsilon \varphi \alpha \dot{\lambda} \alpha 1 \alpha$ and in Latin as capitula. ${ }^{59}$ To the fourth century likewise belong the earliest components of the so-called Euthalian apparatus, which is the most comprehensive attempt to supply all of the New Testament texts, apart from the Gospels, with paratextual content in Greek. The Euthalian edition included for each book (Acts, catholic epistles and Pauline epistles) a pro-

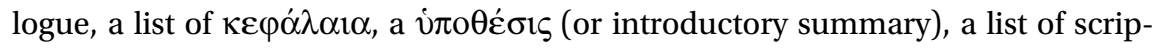
ture citations in the letter (with the title $\alpha v \alpha \kappa \varepsilon \varphi \alpha \lambda \alpha i \omega \sigma ı \varsigma \theta \varepsilon i \omega v \mu \alpha \rho \tau \nu \rho i \omega v$ ) and various other lists and historical information. ${ }^{60}$ It is also worth pointing out that Priscillian's work on the Pauline corpus was not the only paratextual endeavour undertaken by him or those in his movement. Although they were long known as the Prologues of the Monarchians, the four anonymous prefaces to the Gospels that appear in over one hundred Vulgate manuscripts are now widely regarded as in fact traceable to Priscillian himself, or at least to his later followers. ${ }^{61}$ These gospel prologues (combined with the Canons on Paul) evince a great interest within his movement in producing editions of biblical texts equipped with paratextual content, content that long persisted in the Latin biblical tradition despite his association with heresy. ${ }^{62}$

Priscillian's Canons thus fit within a wider interest in the fourth century in producing new editions of sacred texts equipped with paratextual apparatuses, but his creation has the most in common with, and was likely influenced by, the

2000) 179-209; and more recently E. W. Scherbenske, Canonizing Paul: Ancient Editorial Practice and the Corpus Paulinum (Oxford: Oxford University Press, 2013) 85-93, 237-42.

59 On the Greek tradition, see H. F. von Soden, Die Schriften des neuen Testaments in ihrer ältesten erreichbaren Textgestalt auf Grund ihrer Textgeschichte (Berlin: Verlag von Alexander Duncker, 1902). For the Latin material, see De Bruyne's Sommaires, divisions et rubriques de la Bible latine.

60 On the Euthalian apparatus, see N. A. Dahl, "The "Euthalian Apparatus" and the Affiliated "Argumenta"', Studies in Ephesians, 231-75; Blomkvist, Euthalian Traditions; L. C. Willard, A Critical Study of the Euthalian Apparatus (Arbeiten zur neutestamentlichen Textforschung 41; Berlin: Walter de Gruyter, 2009); Scherbenske, Canonizing Paul, 116-74.

61 For an edition and commentary, see Conti, Priscillian of Avila, 250-7, 314-18. See also the discussion in Chadwick, Priscillian of Avilla, 102-9. The identification of these prologues as 'Priscillianist' was made on the basis of a comparison with the Würzburg tractates, carried out by J. Chapman, Notes on the Early History of the Vulgate Gospels (Oxford: Clarendon, 1908) 217-88.

62 The fate of Priscillian's Canons is therefore analogous to the reception in the West of Tatian's Diatessaron, which continued to be copied despite the taint of heresy. Like Peregrinus, Victor of Capua in the sixth-century Codex Fuldensis explained that, Tatian's reputation notwithstanding, his work could still be profitably read. 
Canons for the four Gospels composed by Eusebius. One similarity between the two systems is that they each provide a more precise system of enumeration by breaking a lengthy text up into smaller sections, a feature that, as previously noted, does not appear in any literature prior to this point. Moreover, the

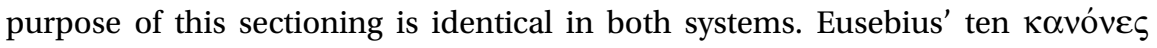
compiled numbers for gospel sections that exhibited parallels between them, and Priscillian arranged his ninety canones so as to bring together Pauline data from across the corpus under dogmatic headings. In other words, among all of the biblical paratexts experimented with in the fourth century, only the systems of Eusebius and Priscillian are not simply paratexts; they are also hypertexts that create a web of textual links across a given corpus. It is also highly probable that Priscillian borrowed his mise-en-page from Eusebius, since he says the sequential numbers for the testimonia are written in the margin of each letter in black, while the number of the appropriate canon is written in red, ${ }^{63}$ the same colour-scheme as that described by Eusebius in his Letter to Carpianus. The fact that Priscillian chose to call his lists of passages canones also implies a likely link with Eusebius, since this native Greek term is very rare in Latin in either pagan or Christian literature prior to this time, and only begins to be regularly used around the time of Priscillian. ${ }^{64}$ If he had simply been looking for a term to refer either to his ninety propositions or to the list of numbers attached to them, canon would hardly have been the obvious choice. ${ }^{65}$ It is unlikely that both Eusebius and Priscillian independently came up with the idea for such a system of numeric cross-referencing, so Priscillian was probably inspired to undertake the task of producing Pauline paratexts by the prior efforts of Eusebius. ${ }^{66}$ It was in the early 380 s that Jerome was busy translating the Gospels, including Eusebius' Canons, into Latin for Pope Damasus, so it is no stretch of the historical imagination to suppose that Priscillian might have been aware of Eusebius' system around the same time further west.

63 Although note that Eusebius was perhaps not entirely original in this respect, since a partially surviving late antique copy of Pliny's letters includes a table of contents written in alternating red and black ink (cf. Gibson, 'Starting with the Index', 41).

64 See e.g. Pliny, Natural History 34.55. According to a search of the Brepolis database, the term does not show up in Christian texts until late fourth-century authors such as Philastrius of Brescia, Ambrose, Rufinus and Augustine. The Oxford Latin Dictionary lists for canon (1) 'the sound-board of a water-organ' and (2) 'a model or standard', neither of which is well suited to Priscillian's use of the term. The sense with which Priscillian uses it is therefore

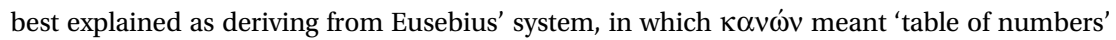

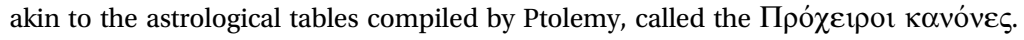

65 One possible designation is caput/capita, which is the title given to unnumbered divisions in Cicero's corpus. See S. Butler, 'Cicero's capita', Roman Paratext, 73-111.

66 Houghton, Latin New Testament, 202, also speculates that 'Priscillian may have been inspired by Jerome's treatment of the Eusebian apparatus, as both refer to the use of contrasting colours of ink'. 
There are, however, two marked differences between the two systems that highlight the way in which Priscillian adapted Eusebius' concept to his own purpose. First, if Eusebius' Canons were stimulated by criticisms of the inconsistency of the four Gospels, this is a fact that he nowhere reveals either in his prefatory Letter to Carpianus or in the internal logic of his apparatus, which in fact resolves nothing. In contrast, Priscillian introduces his Canons on Paul with an explicitly polemical agenda. His system was the result of a request from an anonymous correspondent for 'a very firm bulwark against the heretics' crafty deceit' ${ }^{67}$ Such concerns appear alien to Eusebius' composition (and to the related work of Ammonius prior to him). ${ }^{68}$ The second major difference is immediately obvious from a quick glance at the layout of each work on a page. Eusebius pre-

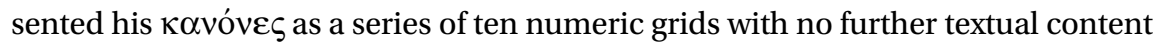
aside from a title at the top of each table noting the number of the canon and the names of the Gospels contained therein. In contrast, Priscillian's system has, for each of the ninety lists of references, a statement standing at the head that integrates the Pauline data under consideration into a single proposition. The addition of these propositions gives his apparatus a theological focus, in contrast to the numerical abstraction of the Eusebian Canons. At least two later users of Eusebius' apparatus made modifications to it that resemble Priscillian's Canons. A sixth-century papyrus from Egypt includes fragments of Eusebius' tables, and alongside some of the numbers in the tables are brief marginal descriptions of the content of the adjacent sections. This, however, was by no means a systematic treatment, and it seems to have been limited to certain passages that were to be read at certain feasts throughout the ecclesiastical year. ${ }^{69}$ A more thorough attempt was made in Codex Brixianus, a sixth-century purple codex in which each parallel in all ten canons was accompanied by the opening words of the scene, an addition that expanded the entire sequence to over 150 pages. $^{70}$

Both of these systems postdate Priscillian, and neither of them extends the usefulness of Eusebius' apparatus to any great degree. Eusebius' goal was not to create a dogmatic table of contents but rather to provide a means of finding parallels among the four Gospels, and to convert his ten canons into a table of contents requires either that one be very selective, or expand the system to ungainly proportions. Moreover, the randomness of the sequence of parallels in Eusebius'

67 The irony of this motivation is of course that Priscillian himself was condemned as a heretic. A concern for heresy also appears in the first of the Würzburg tractates, in which Priscillian denounces a variety of heretical groups such as the Montanists, the Nicholaitans, the Novatians, the Arians and the Manichees.

68 Crawford, 'Ammonius of Alexandria, Eusebius of Caesarea and the Origins of Gospels Scholarship', 1-6.

69 C. Nordenfalk, 'Canon Tables on Papyrus', Dumbarton Oaks Papers 36 (1982) 29-38, 36-7. 70 Nordenfalk, 'Canon Tables on Papyrus', 37. 
system precludes any logical progression through the tables. In contrast, Priscillian's system intends from the outset to be a dogmatic index, with topics arranged roughly according to the order of the church's creed, and by being situated at the head of the Pauline corpus his ninety canons exert a more explicit control over the interpretation of the sacred text that follows. One way of characterising this distinction is to say that Eusebius' system presumes that its user will begin from some point in the midst of reading one of the Gospels and then seek to find parallel passages (the very process he describes in his Letter to Carpianus), while Priscillian's paratext sits at the front of the letters as a key to reassembled Pauline data under dogmatic headings. Two different styles of scholarship are thus encouraged by the two apparatuses: Eusebius' system for the scholar or even casual reader of the Gospels interested in exploring the richness of the gospel tradition, and Priscillian's for the heretic-fighter or homilist who needs a proof-text to win an argument or a statement of dogmatic clarity to distinguish what is errant.

To some degree this distinction between the systems of Eusebius and Priscillian is a result of the differing challenges raised by the Tetraevangelium and the Corpus Paulinum. This is to recall two seminal articles in twentiethcentury New Testament scholarship: Oscar Cullmann's 'The Plurality of the Gospels as a Theological Problem in Antiquity' ${ }^{\prime 1}$ and Nils Dahl's 'The Particularity of the Pauline Epistles as a Problem in the Ancient Church. ${ }^{72}$

As outlined by Cullmann, the challenge with respect to the Gospels was explaining why there was more than one definitive version of the life of Jesus. This plurality threatened to undermine any sense of unity in the Jesus tradition, thereby jeopardising Christianity's claim to truth. By contrast, the challenge with the Pauline letters was that they were such obviously occasional writings, prompted by the specific circumstances of specific churches, that a leap was required to posit the universal applicability of these so very particular texts. Eusebius' Canons for the fourfold Gospel and Priscillian's Canons on Paul may be viewed as attempts to address these divergent challenges. The remarkable achievement of Eusebius' system is that it neither obscures the discrepancies between the four Gospels, nor does it abstract from the fourfold witness to a reconstructed life of Jesus (or a harmony). The numerical abstraction and apparent randomness of the tables ensures the neutrality of the system as a means to study the Gospels themselves, without overtly telling the reader how to reconcile

71 O. Cullmann, 'The Plurality of the Gospels as a Theological Problem in Antiquity', The Early Church: Studies in Early Christian History and Theology (ed. A. J. B. Higgins; Philadelphia: Westminster, 1956) 37-54; original German article in Theologische Zeitschrift 1 (1945) 23-42. 72 N. A. Dahl, 'The Particularity of the Pauline Epistles as a Problem in the Ancient Church', Neotestamentica et Patristica: Eine Freundesgabe Herrn Oscar Cullmann zu seinem 60. Geburstag überreicht (NovTSup 6; Leiden: Brill, 1962) 261-71; reprinted in Studies in Ephesians, 165-78. 
the differences. It thus codifies the plurality of the Gospels without resolving any presumed problem of contradiction. By contrast, Priscillian's Canons directly confront the problem of particularity by generalising the Pauline data, creating synthetic propositional statements that are arranged according to a sequence alien to the Pauline letters. Removed from the circumstances that gave rise to the individual letters, these statements, although presented in Pauline idiom, obtain a timeless quality so as to ensure their universal applicability. ${ }^{73}$ For the problem of gospel plurality, Eusebius' paratextual technology facilitates systematic comparison. For the problem of Pauline particularity, Priscillian's paratextual technology provides an abstract synthesis.

\section{Conclusion}

As Dahl observed, the conundrum for early readers of Paul's letters was in interpreting that collection of ad hoc correspondences as a coherent expression of Christian doctrine. The solution to this conundrum was in developing strategies for generalising the letters, strategies that would enable readers to press their local and time-bound particularity into catholic applicability. But this conundrum and this solution are not restricted to early Christian readers alone. As Dahl also notes, so long as the letters are appropriated as first-order data for the secondorder reconstruction of Pauline theology, 'the tendency towards generalizing interpretation' remains. ${ }^{74}$ While there are certainly multiple ways in which the letters can be generalised and multiple forms in which a system of Paulinism can be developed, what sets the approaches of Priscillian and modern Pauline theologies apart is that both involve processes of 'abstraction' in two senses of the word. First the epistolary data is abstracted in the sense that it is detached from its original context and then relocated in relation to other data from other, often unrelated, contexts. This abstraction of data depends on the innovative technology of precise citation that Priscillian developed. With the letters thus divided

73 The problem of Pauline particularity and Priscillian's attempted solution to it parallel the way the Roman legal tradition operated and developed. Emperors issued legal rulings in ad hoc circumstances, addressing particular cases brought to their attention, though this legislation became universally binding. Later these imperial rescripts were collected into bodies of law, usually stripped of the occasional circumstances that originally gave rise to them. On this topic, see C. Humfress, 'Cracking the Codex: Late Roman Legal Practice in Context', Bulletin of the Institute of Classical Studies 49 (2006) 241-54. Moreover, the legal tradition developed technologies to manage the vast collection of Roman law, employing paratextual devices like tituli and paratitla. Cf. S. Corcoran, 'The Gregorianus and Hermogenianus Assembled and Shattered', Mélanges de l'École Française de Rome - Antiquité 125 (2013) 1-32; M. Wibier, 'The Topography of the Law Book: Common Structures and Modes of Learning', Roman Paratext, 56-72. These suggestive parallels invite further investigation.

74 Dahl, 'The Particularity of the Pauline Epistles', 174. 
into precisely numbered units, the reader could efficiently sort and reorganise the epistolary pieces. The ability to range across the Pauline corpus and easily recombine its elements then occasions the second sense of abstraction, which is the construction of a systematised 'Pauline theology' from the particular, contextually situated epistolary parts.

As Locke long ago complained, with the letters 'chop'd into verses', scholars were then able to reorganise the data 'at randome in theological discourses and disputes as the words in the Original or translations can by ordinary criticism be brought to favour each ones cause or Systeme'. ${ }^{75}$ Although what Locke probably has in mind here are forms of dogmatic proof-texting, the systematic recombination of textual data is precisely what begins to proliferate in early nineteenth-century scholarship. The aim in this, however, was not to fortify some dogmatic system. It was rather an extension of the 'purely historical' interest in Paul - interest in the man 'wie er eigentlich gewesen', to modify Ranke's dictum that lies at the heart of modern criticism. As Locke foresaw, the moveable pieces of Pauline letters 'chop'd into verses' only accelerate the reconstruction of that abstraction.

A millennium and more prior to these modern developments, Priscillian was in search of something as abstract as later historical-critical scholars. If their pursuit was Pauline theology in a purely historical sense, Priscillian's was Pauline theology in a purely dogmatic sense. Priscillian thus went about reconstructing Pauline theology not within the framework of Paul's biography but rather within the framework of received Christian dogma. In contrast to the modern historical critic, who moves beyond the particularity of the Pauline data by abstracting a 'historical Paul', Priscillian moved beyond the particularity of the Pauline letters by abstracting a 'dogmatic Paul', and so a 'Paul' sufficiently systematised to be deployed against false teaching. What both require, however, is an apparatus for cross-referencing Pauline data in order to remake the particular into the general. The numerical simplicity of a precise citation system provided just this, thereby facilitating the abstraction of Paul's thought in both senses of the word. The correspondence of intellectual developments with innovations in reading technology and information management is no accident.

75 Appendix Iv: 'Difficulties in St Paul's Epistles' in Locke, A Paraphrase and Notes on the Epistles, II.673. 